https://doi.org/10.11646/zootaxa.4550.2.3

http://zoobank.org/urn:Isid:zoobank.org:pub:F4EB690C-E509-4C00-94BA-093D5FF2E355

\title{
Two new species of Hippolyte from the Tropical Central and East Atlantic (Crustacea, Decapoda, Caridea)
}

\author{
CHARLES H.J.M. FRANSEN ${ }^{1} \&$ SAMMY DE GRAVE ${ }^{2}$ \\ ${ }^{\prime}$ Taxonomy and Systematics Group, Naturalis Biodiversity Center, P.O. Box 9517, 2300 RA Leiden, The Netherlands. \\ E-mail: charles.fransen@naturalis.nl \\ ${ }^{2}$ Oxford University Museum of Natural History, Parks Road, Oxford, OXI 3PW, United Kingdom
}

\begin{abstract}
Two new species of the caridean shrimp genus Hippolyte Leach, 1814 [in Leach, 1813-14] are described from the Tropical Central and East Atlantic. Hippolyte cedrici sp. nov., from Príncipe and São Tomé, can be distinguished from both the related $H$. holthuisi Zariquey Álvarez, 1953 and $H$. varians Leach, 1814 on the basis of rostral dentition, as well as meristics of the ambulatory pereiopods. Hippolyte karenae sp. nov., from St. Helena, is morphologically similar to H. coerulescens (Fabricius, 1775) and H. obliquimanus Dana, 1852, by having a well-developed tooth on the outer angle of the first peduncular article of the antennula. It differs from these species, amongst other characters, primarily in the armature of the ambulatory dactyli. Specimens were collected from hydrozoan, antipatharian and alcyonarian cnidarians.
\end{abstract}

Key words: Crustacea, Decapoda, Caridea, Hippolytidae, Hippolyte, Tropical Central and East Atlantic, new species

\section{Introduction}

The genus Hippolyte Leach, 1814 [in Leach, 1813-1814] comprises 35 species worldwide (De Grave \& Fransen 2011, Terossi et al. 2017, Gan \& Li 2017a, b). In the temperate to tropical north-eastern Atlantic (including the Mediterranean), the genus is represented by 13 species (d'Udekem d'Acoz 1996, 2007): H. coerulescens (Fabricius, 1775), H. garciarasoi d'Udekem d'Acoz, 1996, H. holthuisi Zariquey Álvarez, 1953, H. inermis Leach, 1815, H. lagarderei d'Udekem d'Acoz, 1995, H. leptocerus (Heller, 1863), H. leptometrae Ledoyer, 1969, H. longiallex d'Udekem d'Acoz, 2007, H. niezabitowskii d'Udekem d'Acoz, 1996, H. palliola Kensley, 1970, $H$. prideauxiana Leach, 1817, H. sapphica d'Udekem d'Acoz, 1993, and $H$. varians Leach, 1814. Further south, few species are known or recorded, with sparse records of $H$. palliola (see Holthuis 1951, as Hippolyte ? longirostris) and $H$. coerulescens (see Holthuis 1951), whilst H. catagrapha d'Udekem d'Acoz, 2007 is presently only known from False Bay in South Africa. In the western Atlantic, the following species have been recorded: H. nicholsoni Chace, 1972, H. obliquimanus Dana, 1852, H. pleuracanthus (Stimpson, 1871), H. zostericola (Smith, 1873), as well as the offshore, amphi-Atlantic $H$. coerulescens.

In his 2007 paper, d'Udekem d'Acoz briefly described and illustrated a damaged ovigerous female specimen of Hippolyte collected from the gorgonian Muriceopsis tuberculata (Esper, 1792) (as M. truncata) from São Tomé, as well as two juvenile specimens collected from the antipatharian Antipathella sp. at Príncipe. Although confident it was a new species, the limited and damaged material precluded naming the species. During a 2017 collecting trip to São Tomé by Dr. Peter Wirtz, more material of this Hippolyte from antipatharian hosts became available. On the basis of this new material, the species is herein fully described and illustrated.

A further new species of Hippolyte, from antipatharians and hydroids, was collected in January 2014 by Dr. Judith Brown (then at the Environment Management Division of St. Helena Government) and Dr. P. Wirtz from several dive sites on the south-central Atlantic Island of St. Helena. This new species is herein also described and illustrated.

Type material is deposited in the collections of Naturalis Biodiversity Centre, Leiden (RMNH) and the 
Zoological Collections of the Oxford University Museum of Natural History (OUMNH.ZC); other abbreviations are: pocl, postorbital carapace length; fcn, field collection number. Geographical co-ordinates are given in decimal degrees.

\section{Systematics}

\section{Order Decapoda Latreille, 1802}

\section{Infraorder Caridea Dana, 1852}

\section{Family Hippolytidae Spence Bate, 1888}

\section{Hippolyte Leach, 1814 [in Leach, 1813-1814]}

\section{Hippolyte cedrici sp. nov.}

(Figs. 1-6)

http://zoobank.org/CB073541-3BA9-4A8D-AE2A-0E2A0F99F44B

Hippolyte sp.—d'Udekem d'Acoz, 2007: 198, Fig. 11.

Hippolyte sp. nov.-Wirtz, 2018: 43.

Material examined. São Tomé Island: holotype ovigerous female (pocl $1.5 \mathrm{~mm}$ ), stn. 22, dive site "Canyon", about 100m west of Santana islet (0.245 6.748), on Tanacetipathes spinescens (Gray, 1857), 34m, leg. P. Wirtz, 6.ii.2017 (RMNH.CRUS.D.57330); 17 paratype specimens (pocl 1.1-1.5 mm), same data (OUMNH.ZC.2018-01076); 11 paratype specimens including 1 ovigerous female (pocl $0.8-1.4 \mathrm{~mm}$ ), stn. 29, same location, on $T$. spinescens, 37m, leg. P. Wirtz, 9.ii.2017 (RMNH.CRUS.D.57331); 9 paratype specimens including 2 ovigerous females (pocl 1.0-1.4 mm), stn. 30, same location, on Antipathella wollastoni (Gray, 1857), 37m, leg. P. Wirtz, 9.ii.2017 (RMNH.CRUS.D.57332).

Description. Carapace stout. In females (Fig. 1A-C), rostrum moderately narrow, as long as or slightly longer than carapace, exceeding antennular peduncle, with postrostral tooth, 3 dorsal teeth on rostrum proper of which distalmost close to tip of rostrum; 2 ventral teeth, distalmost just in front of level of distal dorsal tooth, proximal tooth between level of distal two dorsal teeth. Rostrum in males (Fig. 1B) more slender, slightly shorter than in females, with 3 dorsal teeth and usually one subdistal ventral tooth. Hepatic tooth robust, reaching anterior margin of carapace. Antennal tooth small, just below slightly protruding infraorbital angle. Pterygostomial angle slightly protruding.

Third pleonite (Fig. 1) dorsal outline in lateral view distinctly curved. Fifth pleonite without tooth above tergite-pleuron junction. Ratio between dorsal length and height of sixth pleonite: 3.4. Telson apex (Fig. 6B) with 6 strong terminal cuspidate setae (external ones distinctly shorter than intermediate and median ones); one short cuspidate seta present on each side between intermediate and median ones; usually 4 (sometimes 2 or 3 ) short setae present between long median ones. Proximal pair of dorsolateral cuspidate setae between proximal third and middle of telson (Fig. 6A); distal pair of dorsolateral cuspidate setae usually between first pair and telson apex.

Unpigmented part of eyestalk (Fig. 1A, C) (measured dorsally from where it begins to broaden to base of cornea) longer than broad and longer than cornea. Cornea overreaching stylocerite.

Antennular peduncle (Fig. 1D) reaching 0.7 of scaphocerite in mature females. First joint of antennular peduncle without distal outer tooth. Stylocerite moderately long, reaching 0.7 of first joint of antennular peduncle in mature females. Outer antennular flagellum about as long as inner antennular flagellum. Outer antennular flagellum with 6-9 joints in females: 5-6 thick proximal and 1-3 thin distal joints; first thick joint 1.7 times as long as wide, other thick joints slightly longer than broad or about as long as broad. Inner antennular flagellum with 910 joints. Outer antennular flagellum in males usually with more thick joints than in females.

Scaphocerite of antenna (Fig. 1E) 3.6 times as long as wide. Distolateral tooth of scaphocerite far from reaching tip of blade. Distolateral tooth and blade separated by distinct notch. Basicerite with distinct ventrolateral tooth. Carpocerite short, falling short of distal margin of basal segment of antennular peduncle. 
Mandible (Fig. 2A) with incisor and molar process, without palp. Incisor process with 5 teeth. Molar process with several bristles of short and robust setae.

Maxillula (Fig. 2B) with upper lacinia broadly rectangular with two rows of stout spines medially and few long plumose setae anteriorly and posteriorly. Lower lacinia slender, curled inwards, with few distal serrulate setae. Palp distally with one long, scarcely plumose seta.

Maxilla (Fig. 2C) with basal endite bilobed; distal lobe medially with slender serrulate setae and few long plumose setae anteriorly; proximal lobe slightly larger than distal lobe, medially with serrulate setae. Coxal endite short, medially with row of long plumose setae. Scaphognathite well developed. Palp short, distally with one plumose seta.

First maxilliped (Fig. 2D) with coxal and basal endites partly fused, large and broad; basal endite medially with slender serrulate setae; coxal endite medially with long plumose setae. Exopod well developed, distally with 4 plumose setae; caridean lobe narrow. Epipod small, faintly bilobed. Palp long and slender with plumose setae medially and distally.

Second maxilliped (Fig. 3A) with dactylar segment of endopod about twice as broad as long, densely fringed medially with long serrulate setae. Propodal segment anteriorly with few long simple and plumose setae. Carpal segment short, unarmed, triangular. Meral segment short, unarmed, triangular. Ischial segment slightly longer than broad, ventromedially with row of simple sort setae and dorsomedial row of longer plumose setae. Basal segment medially with long plumose setae; exopod about twice as long as bent endopod, distally with few plumose setae. Coxal segment fused with basal segment, laterally with bilobed epipod.

Third maxilliped (Fig. 3B) reaching about mid-length of scaphocerite when extended forward. Distal segment medially with few rather short serrulate setae, with about 10 large conical teeth on apex and distal third of medial border. Penultimate segment 0.5 times length of distal segment. Antepenultimate segment about as long as distal two segments together, with small distolateral spine, with simple setae in distal $2 / 3^{\text {rd }}$ of medial margin and plumose setae in proximal third of mesial margin; exopod reaching mid-length of antepenultimate segment, distally with few plumose setae. Coxal segment medially expanded with row of plumose setae along medial margin, without epipod nor arthrobranch.

First pereiopod (Fig. 3C) short, compact. Mesial side of chela not deeply concave. Fingers about as long as palm, spatulate, cutting edges entire. Carpus as long as chela, tapering proximally, unarmed. Merus as long as carpus, about twice as long as width, unarmed. Ischium short, basal segment slightly longer, ischial and basal segment combined slightly shorter than merus, medially both with several long plumose setae. Coxal segment almost as long as wide, medially with long plumose seta.

Second pereiopod (Fig. 3D) long and slender, reaching mid-length of scaphocerite when extended. Chela with fingers slightly longer than palm, with entire cutting edges. First joint of carpus about as long as second and third joints combined; first joint 3.0-3.5 times as long as wide, second joint 1.6-1.7, third joint 1.7-1.8 respectively. Merus slender, slightly shorter than carpus. Ischium about half length of merus, unarmed. Basal segment short, half length of ischium, unarmed. Coxal segment medially with few long simple setae.

Ambulatory pereiopods rather long and slender. Third pereiopod (Fig. 3E) almost reaching or slightly overreaching distal margin of scaphocerite when extended forward. Merus in mature females about 7.3 times as long as wide, carpus of third pereiopod 3.6 times as long as wide, propodus 8.7 times as long as wide. Merus with 1 subdistal outer spine. Carpus with 1 proximal outer spine. Propodus with 3 single ventral spinules in proximal 2/ 3 and 3 pairs of ventral spinules in distal third; lateral one in each pair longest. Dactylus (Fig. 5a) about third of propodus length, corpus slightly curved, tapering distally, flexor margin with row of 6 spinules increasing in length distally; unguis slender, twice as long as distalmost spine on corpus (secondary unguis).

Fourth pereiopod (Fig. 4A) similar to third. Merus without subdistal outer spine. Carpus with 1 proximal outer spine. Propodus with 3 single ventral spinules in proximal $2 / 3$ and 3 pairs of ventral spinules in distal third; lateral one in each pair longest. Corpus of dactylus (Fig. 5B) with 5 spinules along flexor margin.

Fifth pereiopod (Fig. 4B) similar to fourth. Propodus with 2 single ventral spinules in proximal $2 / 3$ and 3 pairs of ventral spinules in distal third; lateral one in each pair longest. Corpus of dactylus (Fig. 5C) with 5 spinules along flexor margin.

Eggs small (diameter variable, depending on their developmental stage).

First pleopod of male (Fig. 6D) with endopod less than third length of exopod; medial margin of endopod with row of simple setae; lateral margin of endopod with row of long plumose setae. 


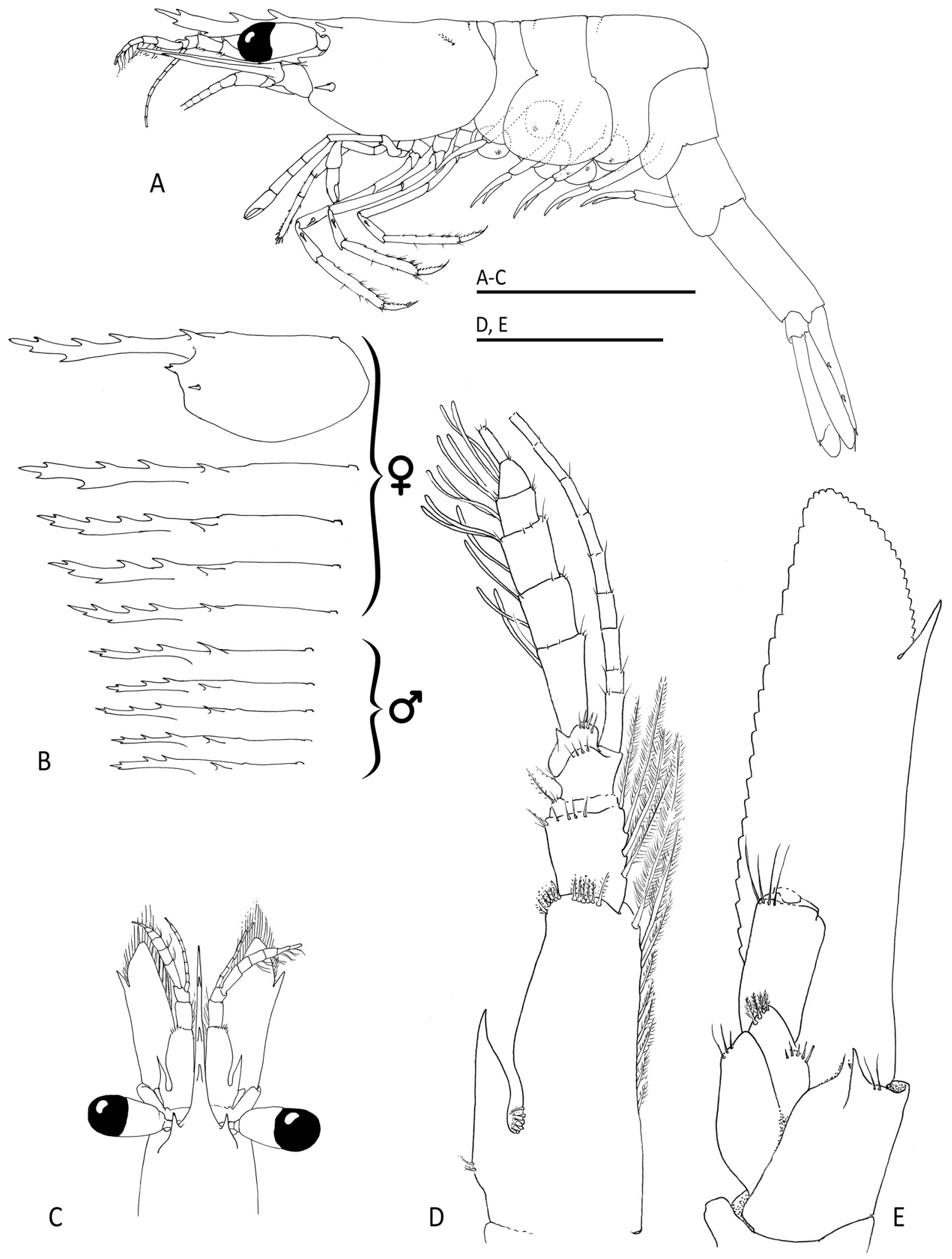

FIGURE 1. Hippolyte cedrici sp. nov., ovigerous female paratype (OUMNH.ZC.2018-01-076): A, habitus, lateral; B, rostral variation; $\mathrm{C}$, anterior carapace and appendages, dorsal view; $\mathrm{D}$, antennula, dorsal view; $\mathrm{E}$, antenna, ventral view. Scale $\mathrm{A}-\mathrm{C}=$ $2 \mathrm{~mm}$; D, E $=0.5 \mathrm{~mm}$. 


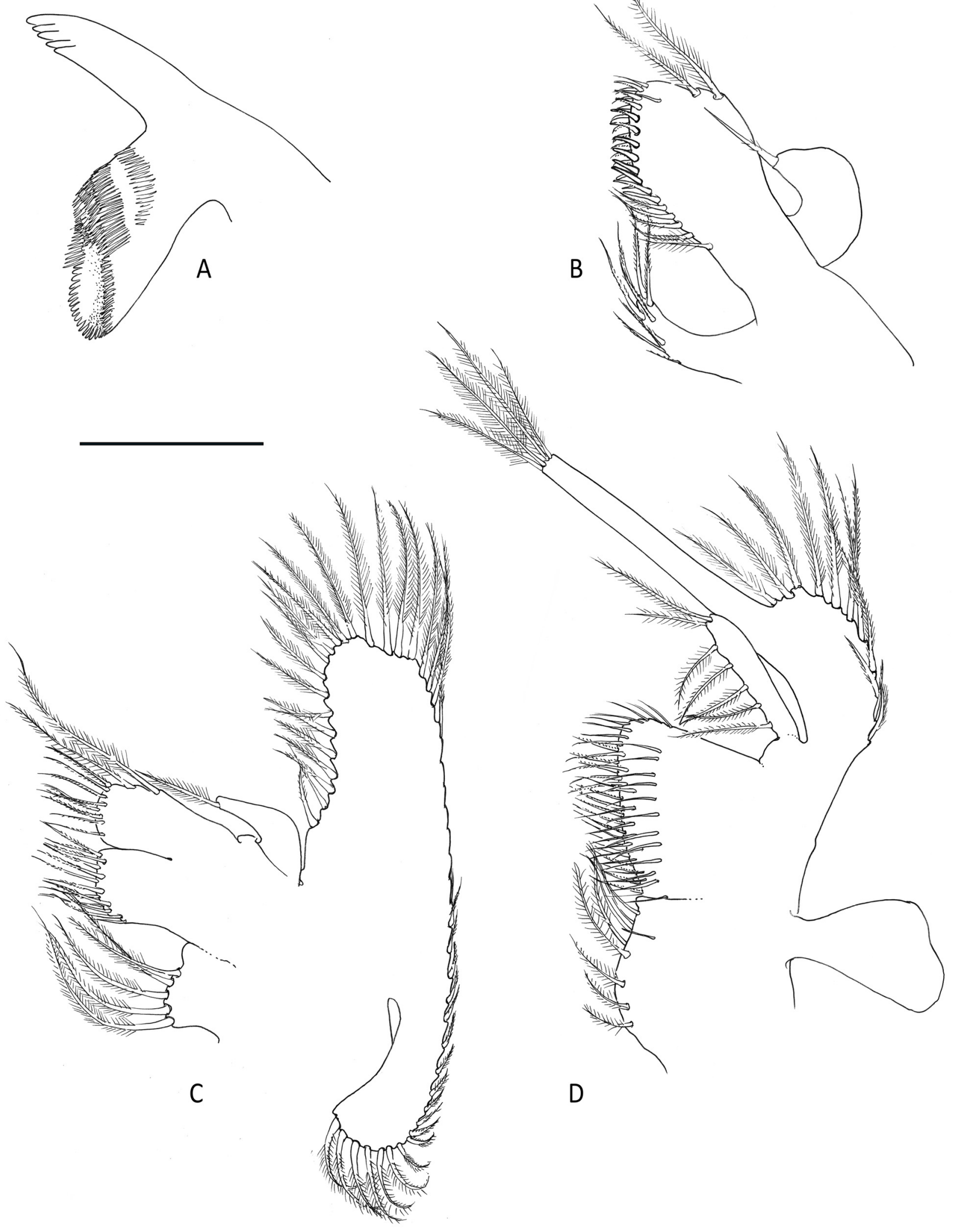

FIGURE 2. Hippolyte cedrici sp. nov., ovigerous female paratype (OUMNH.ZC.2018-01-076): A, left mandible; B, left maxillula; $C$, left maxilla; $D$, left first maxilliped. Scale $=0.25 \mathrm{~mm}$. 

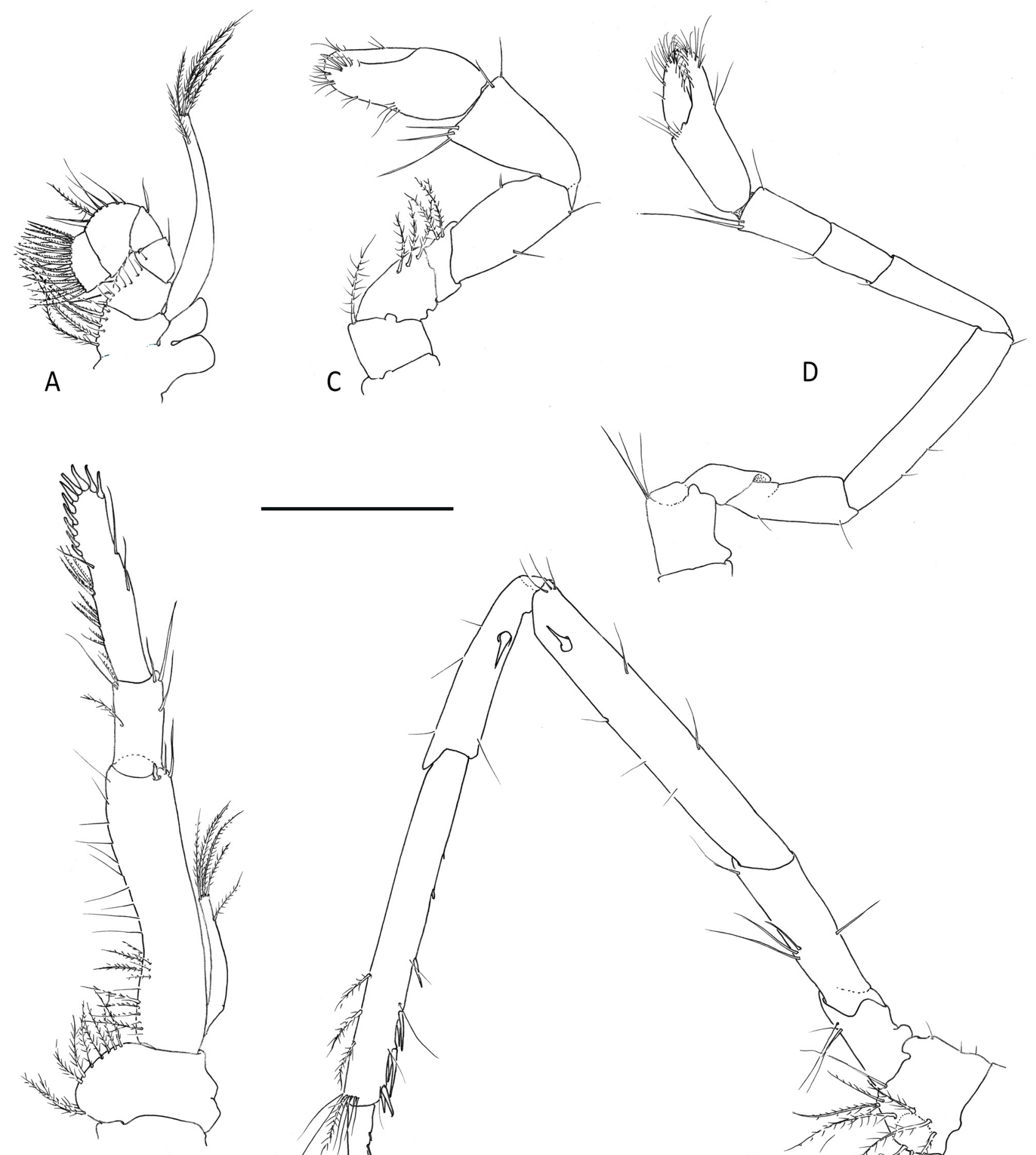

B

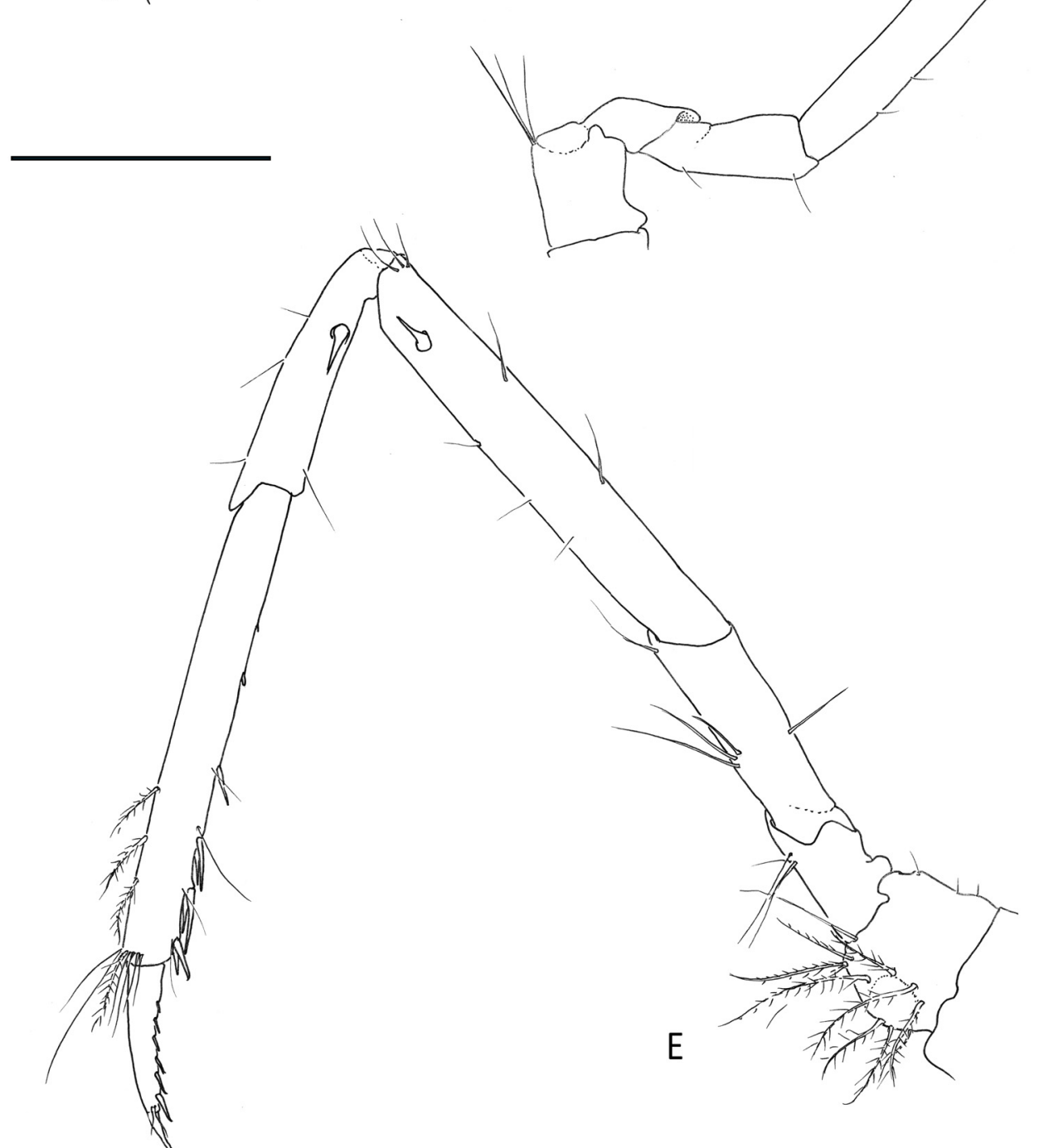

FIGURE 3. Hippolyte cedrici sp. nov., ovigerous female paratype (OUMNH.ZC.2018-01-076): A, left second maxilliped; B, left third maxilliped; $C$, left first pereiopod; D, left second pereiopod; E, left third pereiopod. Scale $=0.5 \mathrm{~mm}$. 


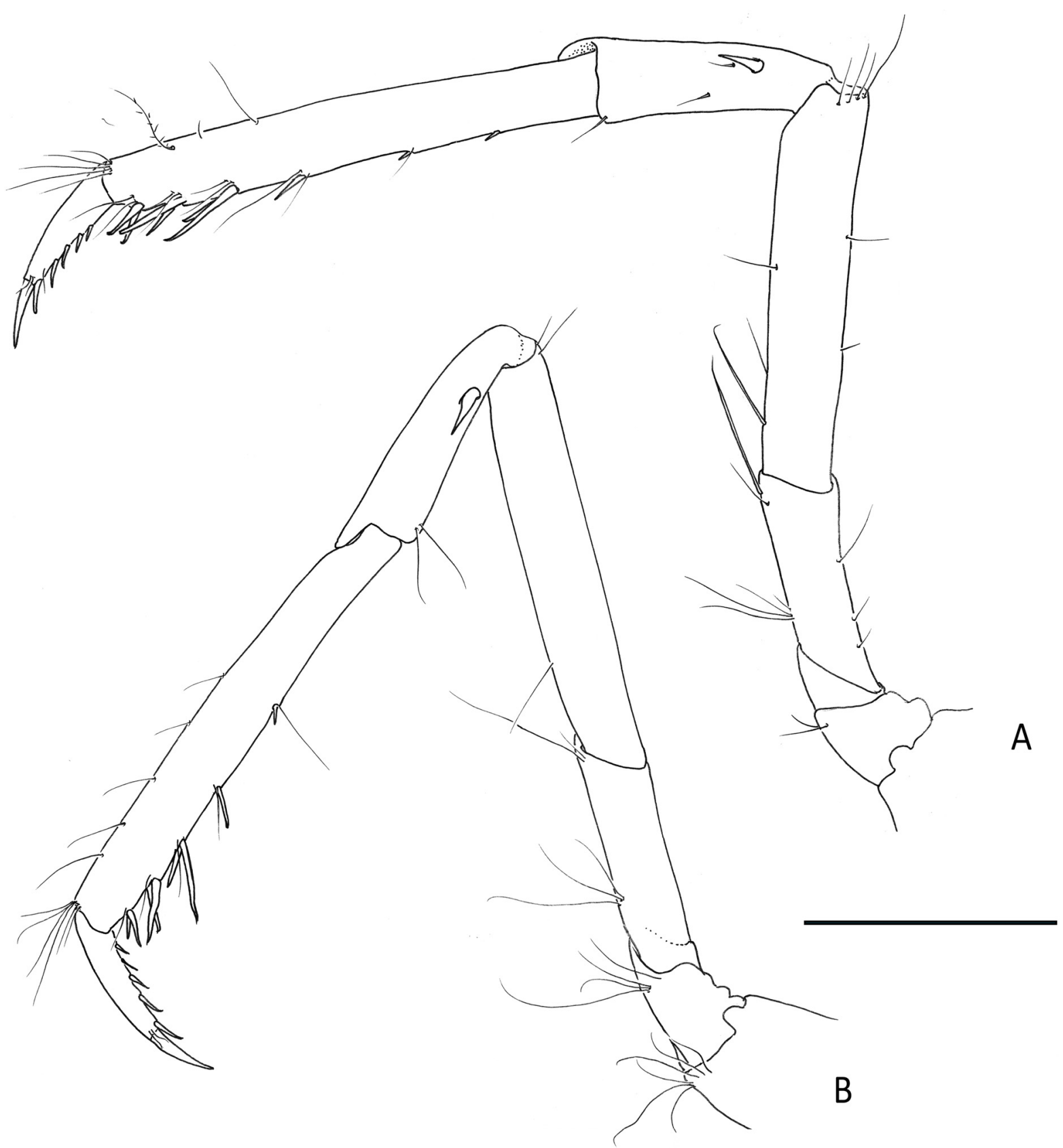

FIGURE 4. Hippolyte cedrici sp. nov., ovigerous female paratype (OUMNH.ZC.2018-01-076): A, left fourth pereiopod; B, left fifth pereiopod. Scale $=0.5 \mathrm{~mm}$.

Second pleopod of male (Fig. 6E) with endopod slightly shorter than exopod; appendix masculina and appendix interna subequal; appendix masculina stout, distally with 6 finely serrulate long setae.

Ambulatory pereiopods in males (Fig. 6C) distoventrally broadened, with series of paired, ventral serrulate spinules.

Colour. Not known.

Measurements. Maximum pocl in ovigerous females $1.6 \mathrm{~mm}$; maximum pocl in males $1.4 \mathrm{~mm}$.

Etymology. Named after our friend and colleague, Dr. Cédric d'Udekem d'Acoz, in recognition for his important contributions to the taxonomy of Hippolyte.

Host. All known specimens were collected from the antipatharians Tanacetipathes spinescens and Antipathella wollastoni, and the alcyonarian Muriceopsis tuberculata [as M. truncata in d'Udekem d'Acoz 2007]. It is not known at this stage whether these records represent obligate or facultative associations. As stated by d'Udekem d'Acoz (2007), given the lack of specific modifications of the ambulatory pereiopods, it could also simply be a ubiquitous species, occasionally encountered on cnidarians. 


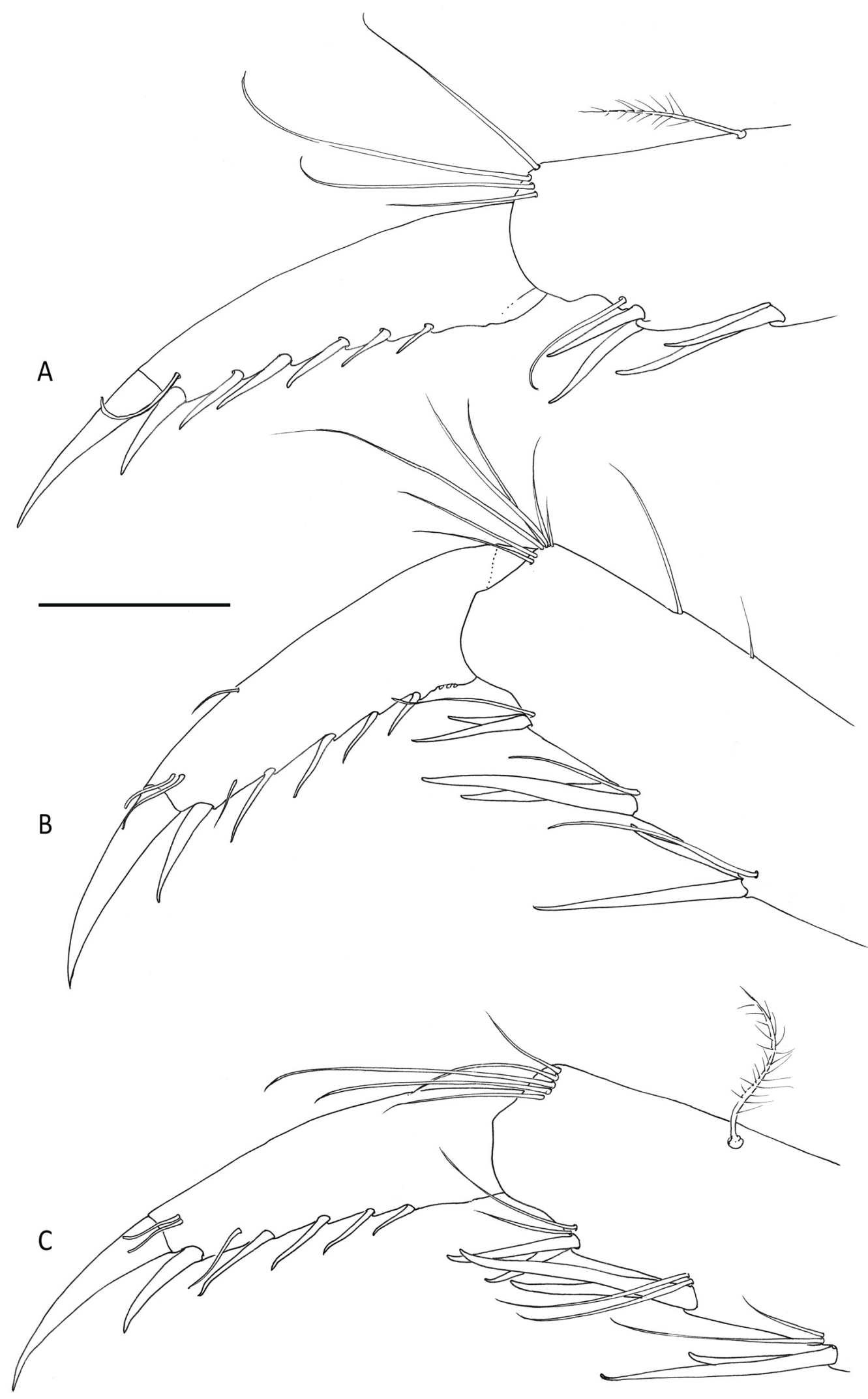

FIGURE 5. Hippolyte cedrici sp. nov., ovigerous female paratype (OUMNH.ZC.2018-01-076): A, right third pereiopod, dactylus, medial view; B, left fourth pereiopod, dactylus, lateral view; C, left fifth pereiopod, dactylus, lateral view. Scale = $0.125 \mathrm{~mm}$. 


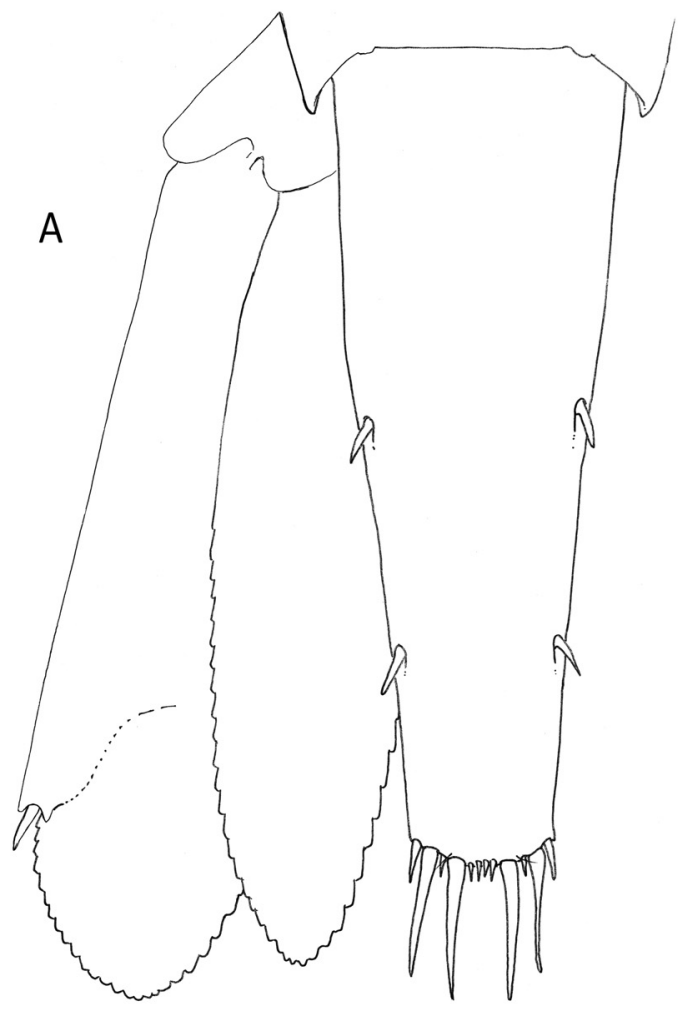

B
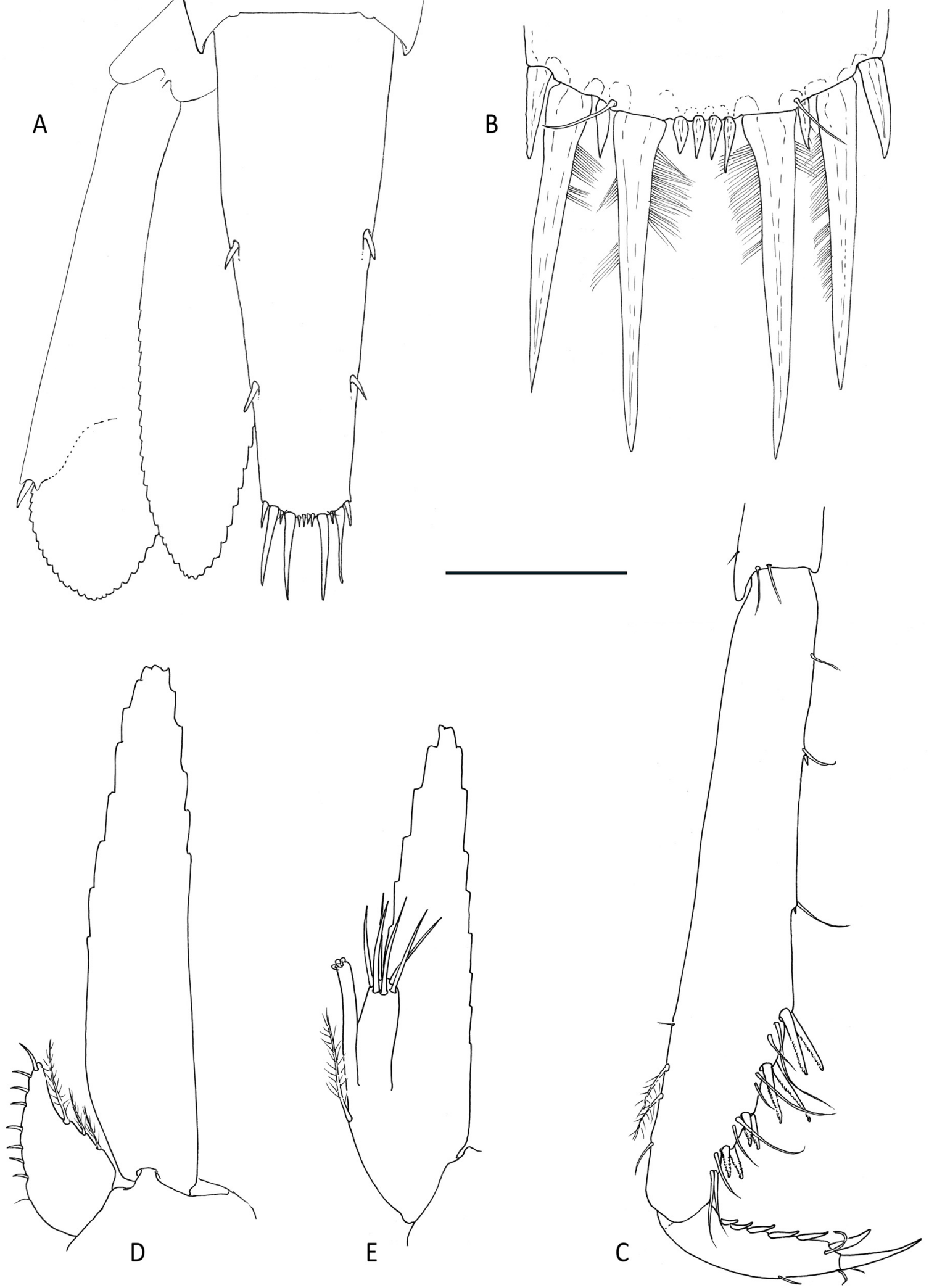

FIGURE 6. Hippolyte cedrici sp. nov. (OUMNH.ZC.2018-01-076). A-B, ovigerous female paratype; C-E male paratype. A, tail fan; B, telson apex; C, right third pereiopod, propodus and dactylus, medial view; D, left first pleopod; E, left second pleopod. Scale A $=0.5 \mathrm{~mm} ; \mathrm{B}=0.125 \mathrm{~mm}$; $-\mathrm{E}=0.25 \mathrm{~mm}$. 
Distribution. Presently only known from São Tomé and Príncipe in the Gulf of Guinea, tropical East Atlantic.

Systematic Remarks. The new species can be easily differentiated from the majority of Atlantic Hippolyte species by the following characters: absence of tooth above tergite-pleuron junction on fifth pleonite (vs. present in $H$. coerulescens); absence of teeth on outer distal corner of first peduncular article of antennula (vs. 2-3 in $H$. obliquimanus); absence of post-rostral teeth (vs. present in H. garciarasoi, H. leptocerus, H. sapphica); distal article of third maxilliped non-setose (vs. setose in H. catagrapha, H. leptometrae); absence of double row of spinules on merus of third and fourth pereiopod (vs. present in H. inermis); presence of single secondary unguis on dactylus of third and fourth pereiopod present (vs. absent in H. longiallex, H. nicholsoni, or with two ungui in $H$. pleuracanthus, H. zostericola); rostrum with dorsal tooth present (vs. absent in H. lagarderei, H. palliola, $H$. prideauxiana) and the distinctly curved dorsal profile of the third pleonite (vs. hardly recurved in $H$. niezabitowskii). The new species thus clearly seems allied to $H$. varians and $H$. holthuisi, as already stated by d'Udekem d'Acoz (2007). The morphological differences between H. holthuisi and $H$. varians are both slight and geographically variable (d'Udekem d'Acoz 1996, 2007, García-Raso et al. 1998), but whilst both taxa have previously been considered to be the same species (d'Udekem d'Acoz 1996), they are clearly genetically distinct (Terossi et al. 2017). Hippolyte cedrici sp. nov. can easily be distinguished from both $H$. holthuisi and $H$. varians on the basis of rostral dentition, with 2 ( 3 in a single specimen) well-developed proximal dorsal teeth in addition to the subdistal dorsal tooth in $H$. cedrici sp. nov., vs. 1 (very rarely 2 ) less developed teeth in the other two species, as well as the lower number of spinules on the dactyli of the ambulatory pereiopods (5-6 vs. 8-11 in the other species). Compared to Atlantic populations of $H$. varians (García-Raso et al. 1998) and the Mediterranean $H$. holthuisi (d'Udekem d'Acoz 1996, García-Raso et al. 1998), the new species also has a lower number of spines on the merus of the third pereiopod, 1 vs. 3-4 in H. holthuisi and 4-7 in H. varians. Finally, the new species has the telson distal margin with an extra set of small cuspidate setae between the median and intermediate long ones which is lacking in $H$. varians and H. holthuisi.

\section{Hippolyte karenae sp. nov.}

(Figs. 7-13)

http://zoobank.org/21E17642-C84D-44ED-BDAC-3C69E3728E3E

Material examined. St. Helena: holotype ovigerous female (pocl $1.5 \mathrm{~mm}$ ), on Macrorhynchia filamentosa (Lamarck, 1816), 20.4m, Speery Island (-16.029 -5.753), leg. P. Wirtz \& J. Brown, 16.i.2014, fcn 14016/6305 (RMNH.CRUS.D.57333); 17 paratype specimens (pocl 0.6-1.6 mm), same data (RMNH.CRUS.D.57334); ovigerous female paratype (pocl $1.3 \mathrm{~mm}$ ) same data, fcn 140116/63/02-03 (OUMNH.ZC.2018-04-009); 6 paratype specimens, including 2 ovigerous females (pocl 0.6-1.3 mm), on Plumapathes pennacea (Pallas, 1766), 15.0m, Long Ledge (-15.945 -5.753), leg. P. Wirtz \& J. Brown, 14.i.2014, fen 140114/60/3-6-7 (OUMNH.ZC.2018-4010); 5 paratype specimens, including 3 ovigerous females (pocl $0.6-1.5 \mathrm{~mm}$ ), on M. filamentosa, 20.5m, Windy Cove (-15.998 -5.786), leg. P. Wirtz \& J. Brown, 29.i.2014, fen 140119/83/01 (preserved with host) (OUMNH.ZC.2018-04-011).

Description. Carapace stout. In females (Fig. 7A-C), rostrum moderately narrow, shorter than carapace, slightly exceeding antennular peduncle, with 3 dorsal teeth on rostrum proper of which distalmost close to tip of rostrum; 2 ventral teeth, distal tooth subapical, proximal tooth in front of level of distalmost dorsal tooth. Rostrum in males (Fig. 7B) more slender and shorter than in females, with 1-3 dorsal teeth and usually one subdistal ventral tooth. Hepatic tooth robust, reaching anterior margin of carapace. Antennal tooth small, just below slightly protruding infraorbital angle. Pterygostomial angle slightly protruding.

Third pleonite of abdomen (Fig. 7A) dorsal outline in lateral view distinctly curved. Ratio between dorsal length and height of sixth pleonite: 2.7 .

Telson (Fig. 12B) with proximal pair of dorsolateral cuspidate setae between proximal third and middle of telson length; distal pair of dorsolateral cuspidate setae usually between first pair and telson apex. Telson apex (Fig. 12C) with 6 strong terminal cuspidate setae (external distinctly shorter than intermediate and median ones); 2 short ones present between long median ones.

Unpigmented part of eyestalk (Fig. 7A, C) (measured dorsally from point where it begins to broaden to base of cornea) longer than broad and longer than cornea. Cornea not overreaching stylocerite.

Antennular peduncle (Fig. 7D) reaching 0.6 of scaphocerite in mature females. First joint of antennular 
peduncle with strong distal outer tooth. Stylocerite long, reaching 0.8-0.9 of first joint of antennular peduncle in mature females. Outer antennular flagellum about as long as inner antennular flagellum. Outer antennular flagellum with 8-9 joints in females: 5-6 thick proximal and 2-3 thin distal joints; first thick joint 1.6 times as long as wide, other thick joints about as long as broad. Inner antennular flagellum with about 10 joints. Outer antennular flagellum in males usually with sturdier joints than in females.

Scaphocerite of antenna (Fig. 7E) 2.7 times as long as wide. Distolateral tooth of scaphocerite far from reaching tip of blade. Distolateral tooth and blade separated by distinct notch. Basicerite with distinct ventrolateral tooth. Carpocerite short, falling short of distal margin of basal segment of antennular peduncle.

Mandible (Fig. 8A) with incisor and molar process, palp absent. Incisor process with 4 teeth. Molar process with several bristles of short and robust setae.

Maxillula (Fig. 8B) with upper lacinia broadly rectangular, medially with two rows of stout spines and few long plumose setae anteriorly and posteriorly. Lower lacinia slender, curled inward, distally with few serrulate setae. Palp distally with one long plumose seta.

Maxilla (Fig. 8C) with basal endite bilobed; distal lobe medially with slender serrulate setae and anteriorly with few long plumose setae; proximal lobe slightly larger than distal lobe, medially with serrulate setae. Coxal endite short, medially with row of long plumose setae. Scaphognathite well developed. Palp short, distally with one plumose seta.

First maxilliped (Fig. 8D) with coxal and basal endites partly fused, large and broad; basal endite medially with slender serrulate setae; coxal endite medially with long plumose setae. Exopod well-developed, distally with 4 plumose setae; caridean lobe narrow. Epipod small, faintly bilobed. Palp long and slender with plumose setae medially and distally.

Second maxilliped (Fig. 9A) with dactylar segment of endopod almost twice as broad as long, medially densely fringed with long serrulate setae. Propodal segment anteriorly with few long plumose setae. Carpal segment short, unarmed, triangular. Meral segment short, unarmed, triangular. Basal and ischial segment fused, slightly longer than broad, medially with row of long plumose setae; exopod about twice as long as endopod, with few plumose setae distally and proximally. Coxal segment partly fused with basal segment, laterally with bilobed epipod.

Third maxilliped (Fig. 9B) reaching about mid-length of scaphocerite when extended forward. Distal segment medially with few, rather short serrulate setae, with about 8 large conical teeth on apex and distal third of medial border (Fig. 9C). Penultimate segment 0.3 times length of distal segment. Antepenultimate segment almost as long as distal segment, without distolateral spine, with few plumose setae on mesial margin. Basal segment medially with row of plumose setae; exopod as long as basal segment, with row of few plumose setae in distal half. Coxal segment without epipod nor arthrobranch.

First pereiopod (Fig. 9D) short, compact. Fingers about as long as palm, spatulate, with serrate cutting edges. Carpus shorter than chela, tapering proximally, excavate distally, unarmed. Merus as long as chela, about twice as long as wide, mesially with row of long plumose setae. Ischium much shorter than merus, medially with several long plumose setae. Basal segment about as long as wide, medially with long plumose seta.

Second pereiopod (Fig. 9E) long and slender, reaching mid-length of scaphocerite when extended. Chela with fingers as long as palm, cutting edges entire. First joint of carpus about as long as third joint, second joint distinctly shorter; first joint 2.0 times as long as wide, second joint 1.1, third joint 1.6 respectively. Merus slender, slightly shorter than carpus. Ischium about half length of merus, unarmed, two-jointed. Basal segment short, half length of ischium, unarmed. Coxal segment medially with few long simple setae.

Ambulatory pereiopods rather long and robust. Third pereiopod (Fig. 10A) almost reaching or slightly overreaching distal margin of scaphocerite when extended forward. Merus in mature females about 5.3 times as long as wide, carpus of third pereiopod 2.3 times as long as wide, propodus 6.0 times as long as wide. Merus with 1-3 subdistal outer spines. Carpus with 1-2 proximal outer spines. Propodus with 2 single ventral spinules in proximal half and 3 pairs of ventral spinules in distal third; lateral one in each pair longest; one distolateral spinule. Dactylus (Fig. 11A) about 0.45 of propodus length, corpus slightly curved, tapering distally, flexor margin with row of 9 spinules increasing in size distally except for unguis which is slightly smaller than subdistal spinule.

Fourth pereiopod (Fig. 10B) similar to third. Merus with one subdistal outer spine, seldom absent. Carpus with one proximal outer spine. Propodus with 3 single ventral spinules in proximal $2 / 3$ and 3 pairs of ventral spinules in distal third. Dactylus (Fig. 11B) as in third pereiopod. 

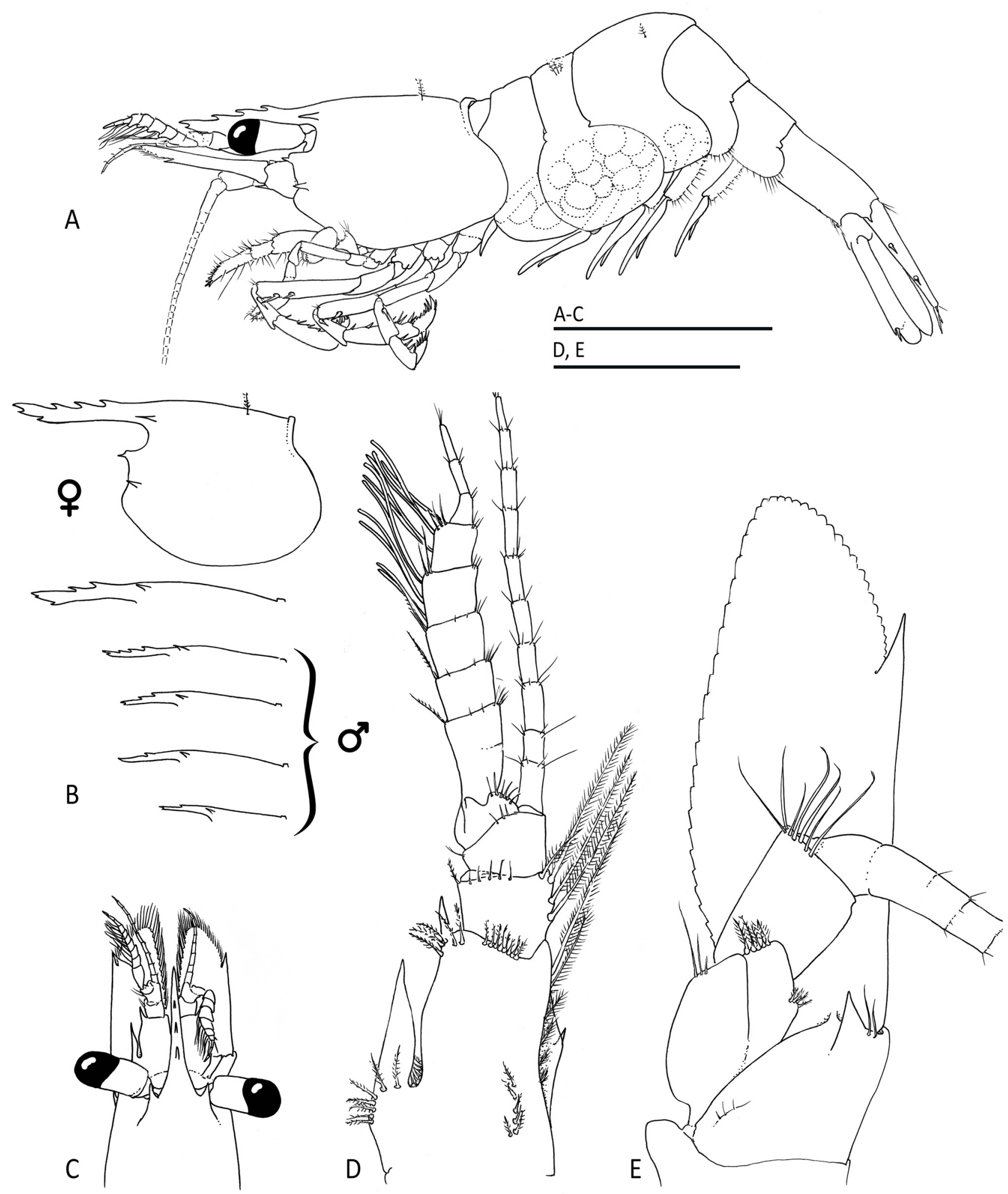

FIGURE 7. Hippolyte karenae sp. nov., ovigerous female paratype (RMNH.CRUS.D.57334): A, habitus, lateral; B, rostral variation; $\mathrm{C}$, anterior carapace and appendages, dorsal view; $\mathrm{D}$, antennula, dorsal view; $\mathrm{E}$, antenna, ventral view. Scale $\mathrm{A}-\mathrm{C}=$ $2 \mathrm{~mm} ; \mathrm{D}, \mathrm{E}=0.5 \mathrm{~mm}$. 


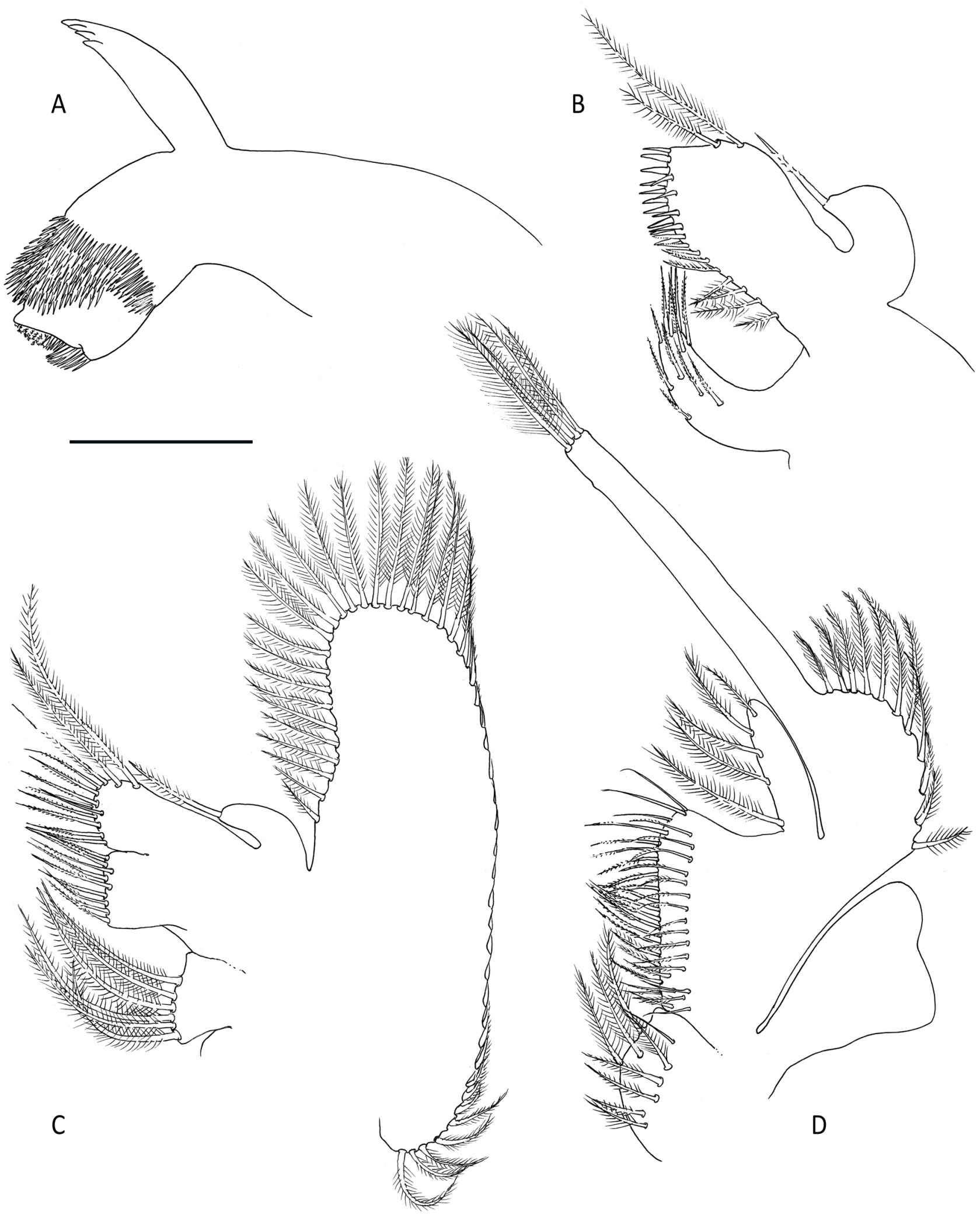

FIGURE 8. Hippolyte karenae sp. nov., ovigerous female paratype (RMNH.CRUS.D.57334): A, left mandible; B, left maxillula; C, left maxilla; D, left first maxilliped. Scale $=0.25 \mathrm{~mm}$. 


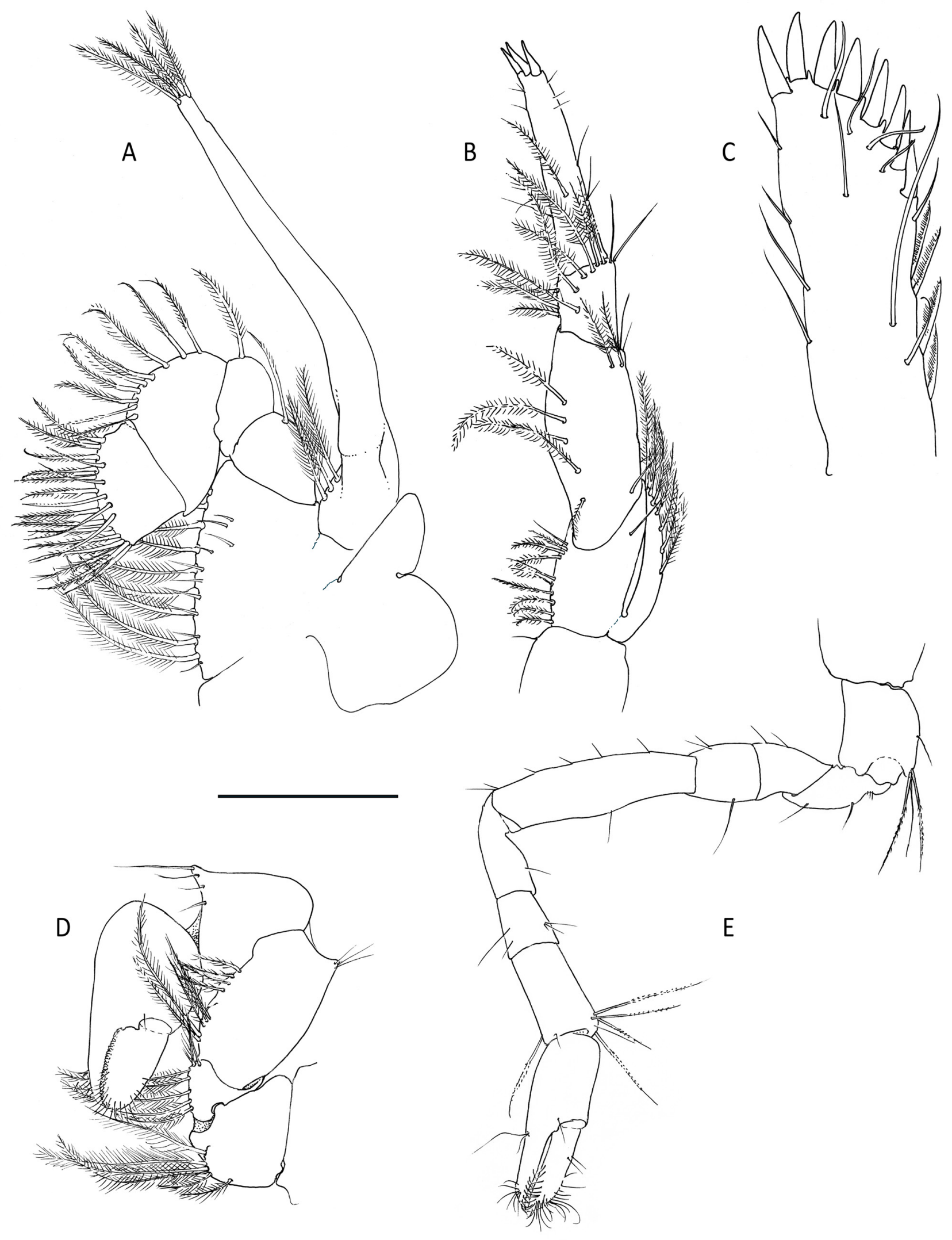

FIGURE 9. Hippolyte karenae sp. nov., ovigerous female paratype (RMNH.CRUS.D.57334): A, left second maxilliped; B, left third maxilliped; $\mathrm{C}$, idem, distal part of ultimate segment; D, left first pereiopod; E, left second pereiopod. Scale A, C = $0.25 \mathrm{~mm} ; \mathrm{B}, \mathrm{D}, \mathrm{E}=0.5 \mathrm{~mm}$. 


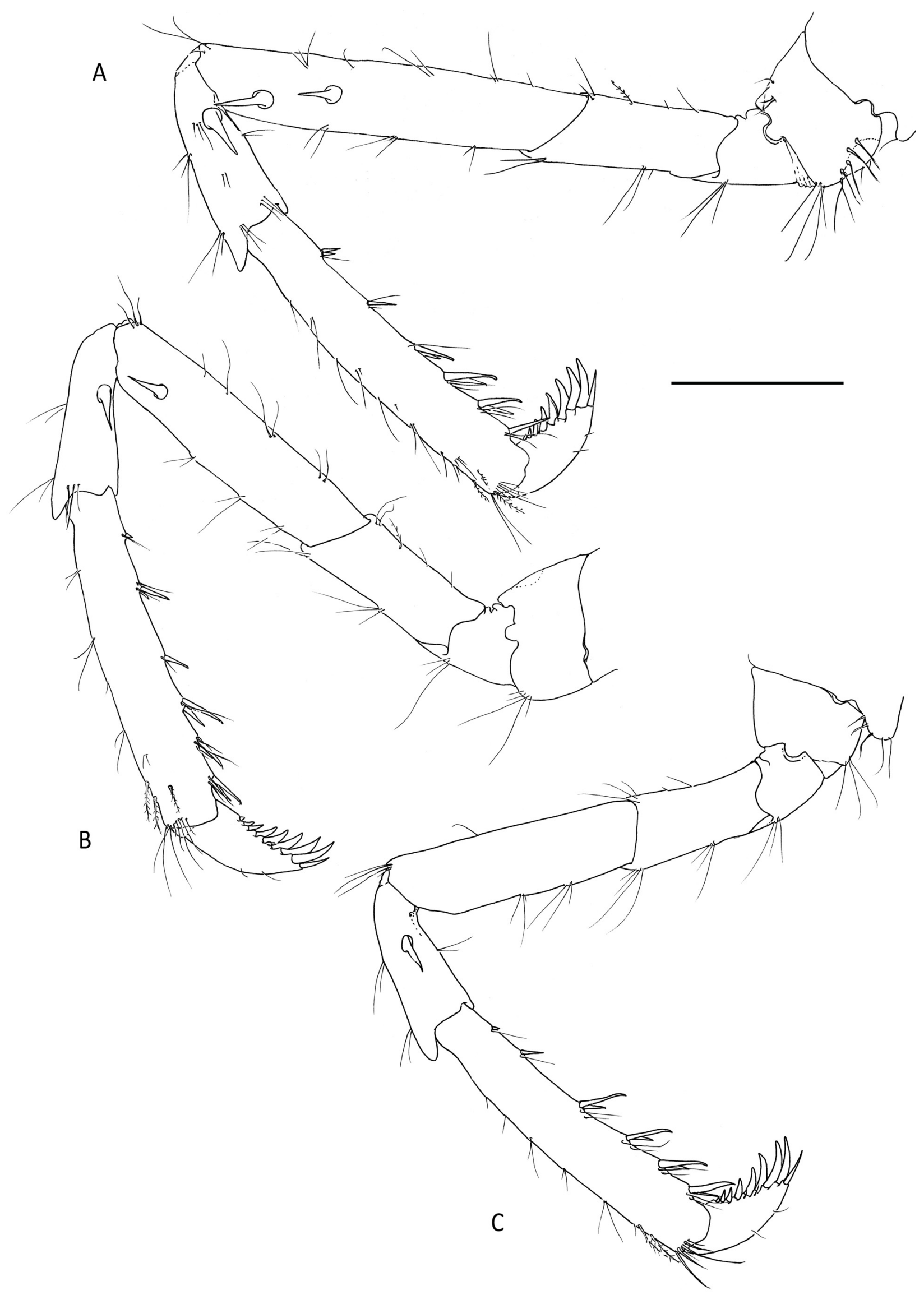

FIGURE 10. Hippolyte karenae sp. nov., ovigerous female paratype (RMNH.CRUS.D.57334): A, left third pereiopod; B, left fourth pereiopod; C, left fifth pereiopod. Scale $=0.5 \mathrm{~mm}$. 


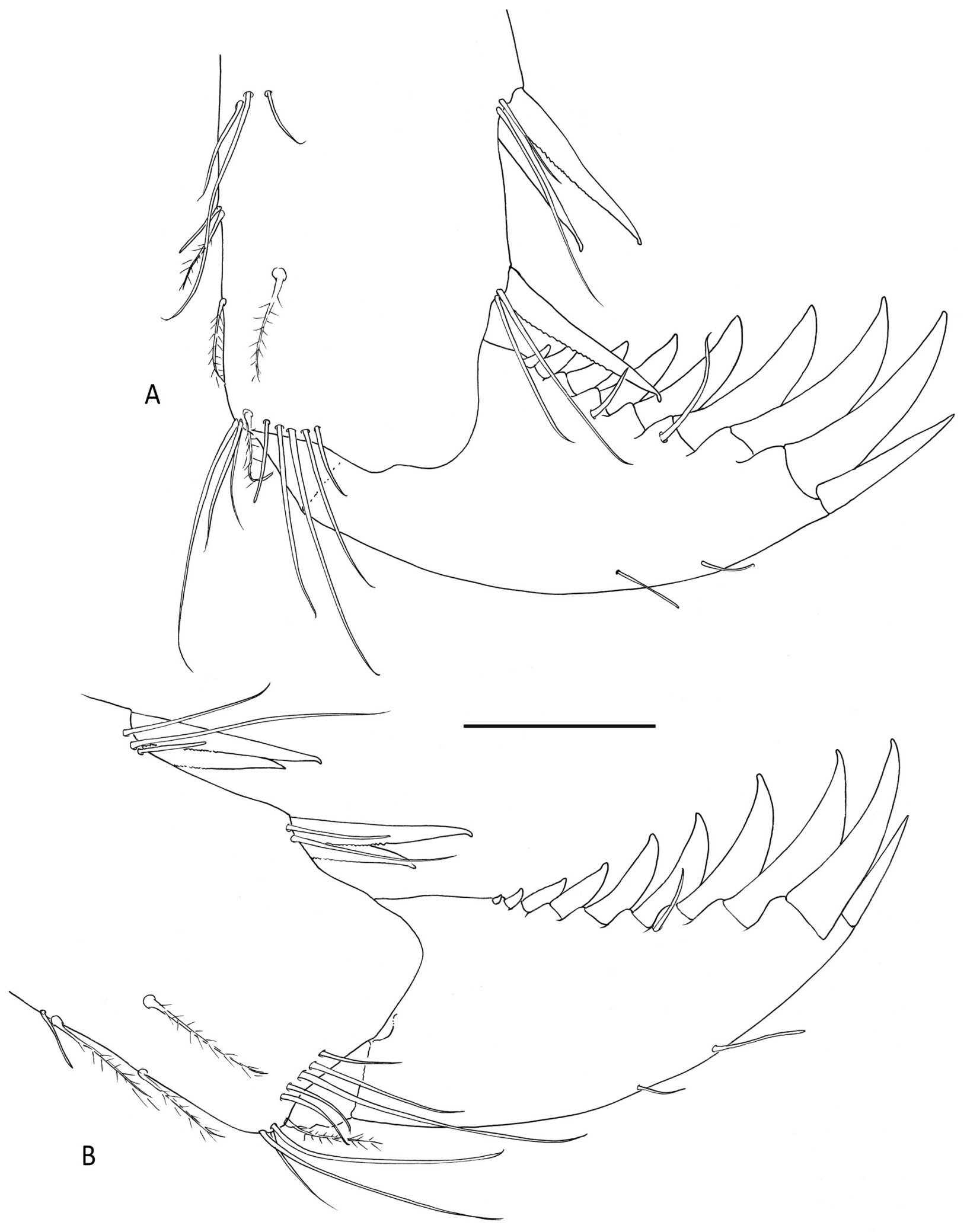

FIGURE 11. Hippolyte karenae sp. nov., ovigerous female paratype (RMNH.CRUS.D.57334): A, left third pereiopod, dactylus, lateral view; B, left fourth pereiopod, dactylus, lateral view; C, left fifth pereiopod, dactylus, lateral view. Scale = $0.125 \mathrm{~mm}$. 


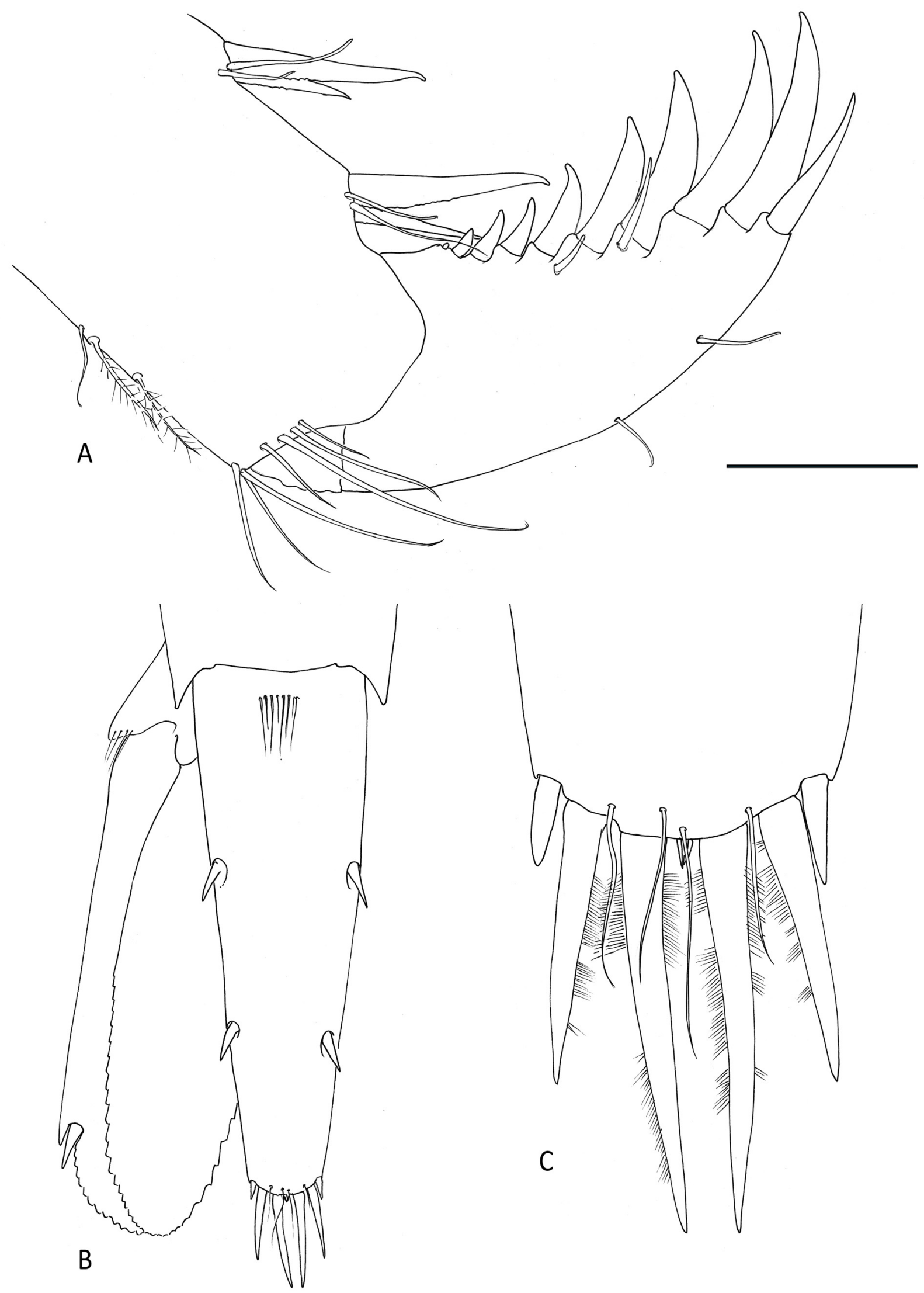

FIGURE 12. Hippolyte karenae sp. nov., ovigerous female paratype (RMNH.CRUS.D.57334): A, left fifth pereiopod, dactylus, lateral view; $B$, tail fan; $C$, telson apex. Scale A, $C=0.125 \mathrm{~mm} ; \mathrm{B}=0.5 \mathrm{~mm}$. 

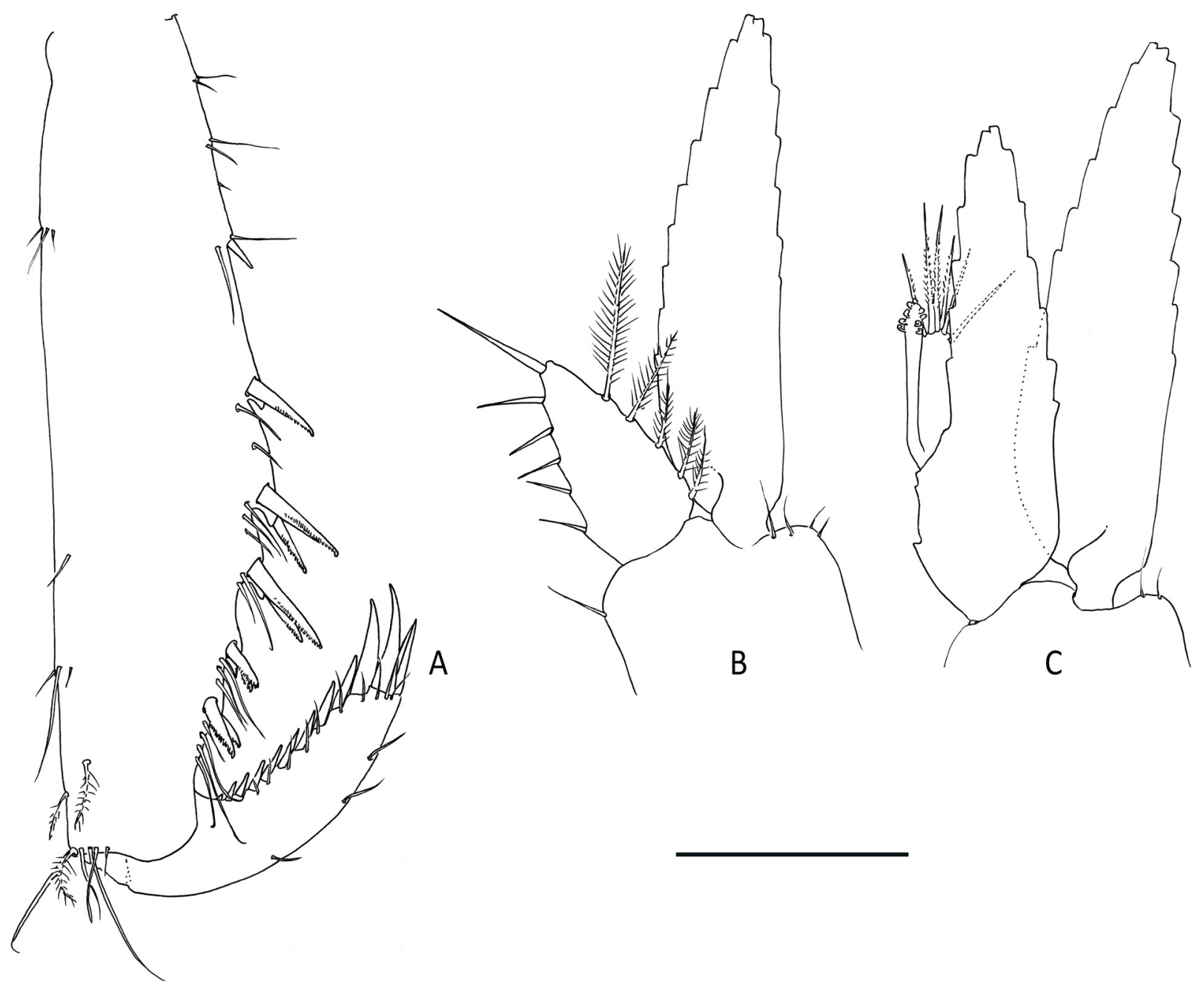

FIGURE 13. Hippolyte karenae sp. nov., male paratype (RMNH.CRUS.D.57334). A, left third pereiopod, propodus and dactylus, lateral view; $\mathrm{B}$, left first pleopod; $\mathrm{C}$, left second pleopod. Scale $=0.25 \mathrm{~mm}$.

Fifth pereiopod (Fig. 10C) similar to third and fourth. Merus without spines. Carpus without or with single proximal outer spine. Propodus with 2 single ventral spinules in proximal third, with 4 pairs of spinules in distal 2/ 3. Dactylus (Fig. 12A) as in third and fourth pereiopod, with 10 spinules on flexor margin, including unguis.

Eggs small (diameter variable, depending on their developmental stage).

First pleopod of male with endopod less than half length of exopod; medial margin of endopod with row of simple setae; lateral margin of endopod with row of long plumose setae.

Second pleopod of male with endopod slightly shorter than exopod; appendix masculina and appendix interna subequal; appendix masculina distally with 6 finely serrulate long setae.

Ambulatory pereiopods in males distoventrally broadened with series of paired ventral serrulate spinules.

Colour. Not known.

Measurements. Maximum pocl in ovigerous females $1.5 \mathrm{~mm}$; maximum pocl. in males $1.3 \mathrm{~mm}$.

Etymology. This species is named in honour of Karen van Dorp, who for more than

10 years was the exemplary collection manager of the crustacean collection of Naturalis Biodiversity Center in Leiden, the Netherlands.

Host. All known specimens were collected from the hydroid Macrorhynchia filamentosa (Lamarck, 1816) and the antipatharian Plumapathes pennacea (Pallas, 1766). It is not know at this stage whether these records represent obligate or facultative associations.

Distribution. Presently only known from St. Helena in the tropical South-Central Atlantic.

Systematic remarks. The new species differs from all previously described Atlantic species of the genus, 
except $H$. coerulescens and $H$. obliquimanus, by having a well-developed tooth on the outer angle of the first peduncular article of the antennula. Hippolyte karenae sp. nov. can be easily distinguished from $H$. coerulescens by the absence of a postero-dorsal tooth on the fifth pleonite (vs. present in H. coerulescens), as well as by the shape of the rostrum, dorsal outline of the third pleonite and the different armature of the dactyli of the ambulatory pereiopods. In general morphology, the new species is somewhat reminiscent of the western Atlantic $H$. obliquimanus, but can be distinguished from that species by having one tooth on the outer angle of the first peduncular article of the antennula in adults (vs. 2-3 in H. obliquimanus, but sometimes only 1 in juveniles, see d'Udekem d'Acoz 1997). A further clear difference between both species is the armature and shape of the dactyli of the ambulatory pereiopods, with the dactyl being robust in H. karenae sp. nov. (vs. gracile in H. obliquimanus), the much more stronger developed accessory spinules in H. karenae sp. nov., the presence of two secondary ungui in H. obliquimanus (vs. absent in H. karenae sp. nov., although with several distal accessory spinules strongly developed).

\section{Acknowledgements}

Dr. Judith Brown (then at the Environment Management Division of St. Helena Government) and Dr. Peter Wirtz (Centro de Ciências do Mar, Universidade do Algarve) are gratefully acknowledged for collecting specimens and entrusting us with their description. Two non-anonymous reviewers provided much appreciated feed-back.

\section{References}

Chace, F.A. Jr. (1972) The shrimps of the Smithsonian-Bredin Caribbean expeditions with a summary of the West Indian shallow-water species (Crustacea: Decapoda: Natantia). Smithsonian Contributions to Zoology, 98, 1-179. https://doi.org/10.5479/si.00810282.98

Dana, J.D. (1852) United States Exploring Expedition during the years 1838, 1839, 1840, 1841, 1842, under the Command of Charles Wilkes, U.S.N. Vol. 13. Crustacea. Part I. C. Sherman, Philadelphia, $685+27$ pp., 96 pls. [1855]

De Grave, S. \& Fransen, C.H.J.M. (2011) Carideorum Catalogus: The recent species of the dendrobranchiate, stenopodidean, procarididean and caridean shrimps (Crustacea: Decapoda). Zoologische Mededelingen, 85, 195-589.

d'Udekem d'Acoz, C. (1993) Description d'une nouvelle crevette de l'île de Lesbos: Hippolyte sapphica sp. nov. (Crustacea, Decapoda, Caridea, Hippolytidae). Belgian Journal of Zoology, 123 (1), 55-65.

d'Udekem d'Acoz, C. (1995) Sur trois Hippolyte de l'Atlantique Nord-Oriental et de la Méditerranée: H. lagarderei sp. nov., H. varians Leach, 1814 et $H$. holthuisi Zariquiey Álvarez, 1953 (Decapoda, Caridea). Crustaceana, 68 (4), 494-502. https://doi.org/10.1163/156854095X00719

d'Udekem d'Acoz, C. (1996) The genus Hippolyte Leach, 1814 (Crustacea; Decapoda; Caridea; Hippolytidae) in the East Atlantic Ocean and the Mediterranean Sea, with a checklist of all species in the genus. Zoologische Verhandelingen Leiden, 303, 1-133.

d'Udekem d'Acoz, C. (1997) Redescription of Hippolyte obliquimanus Dana, 1852, and comparison with Hippolyte williamsi Schmitt, 1924 (Decapoda, Caridea). Crustaceana, 70, 469-479. https://doi.org/10.1163/156854097X00050

Esper, E.J.C. (1792) Die Pflanzenthiere in Abbildungen nach der Natur mit Farben erleuchtet nebst Beschreibungen. 2 (1792). in der Raspischen Buchhandlung, Nürnberg, 32 pp. [pp. 133-164]

Fabricius, J.C. (1775) Systema Entomologiae, sistens Insectorum Classes, Ordines, Genera, Species, adiectis Synonymis, Locis, Descriptionibus, Observationibus. In Officina Libraria Kortii, Flensbvrgi et Lipsiae, 832 pp.

Gan, Z. \& Li, X. (2017a) A new species of the genus Hippolyte (Decapoda: Caridea: Hippolytidae) from South China Sea and Singapore. Zootaxa, 4258 (1), 34-42. https://doi.org/10.11646/zootaxa.4258.1.2

Gan, Z. \& Li, X. (2017b) A new species of the genus Hippolyte (Decapoda: Caridea: Hippolytidae) from Singapore. Raffles Bulletin of Zoology, 65, 207-212.

García-Raso, J.E., Manjón-Cabeza, M.E. \& Martínez, J.C.I. (1998) Considerations on some species of Hippolyte (Decapoda, Caridea) from southern European waters, H. niezabitowskii, H. holthuisi, and H. varians. Crustaceana, 71, 453-467. https://doi.org/10.1163/156854098X00545

Heller, C. (1863) Die Crustaceen des Südlichen Europa. Crustacea Podophthalmia. Wilhelm Braumüller, Wien, xi + 336 pp., 10 pls.

Holthuis, L.B. (1951) The caridean Crustacea of Tropical West Africa. Atlantide Report, 2, 7-187.

Kensley, B.F. (1970) Some decapod Crustacea from northern South Africa, including a new species of Hippolyte. Cimbebasia, 
(A), 1 (9), 179-188.

Lamarck, J.B.P.A. de (1816) Histoire naturelle des animaux sans vertèbres. Vol. 2. Verdière, Paris, 568 pp.

Latreille, P.A. (1802) Histoire naturelle, générale et particulière des crustacés et des insectes. Vol. 6. F. Dufart, Paris, 391 pp., pls. 44-57.

Leach, W.E. (1813-1814) Crustaceology. In: Brewster, D., The Edinburgh Encyclopcedia. A. Balfour, Edinburgh, pp. $383-437$.

Leach, W.E. (1815-1875) Malacostraca Podophthalmata Britanniae; or, descriptions of such British species of the Linnean genus Cancer as have their eyes elevated on footstalks. J. Sowerby, London, 124 pp. (unnumbered), $45 \mathrm{pls.}$

Ledoyer, M. (1969) Remarques sur les Hippolytidae des côtes de Provence et description de Hippolyte leptometrae n. sp. Tethys, 1 (2), 341-348.

Pallas, P.S. (1766) Elenchus Zoophytorum Sistens Generum Adumbrationes Generaliores et Specierum Cognitarum Succinctas Descriptiones cum Selectis Auctorum Synonymis. Apud Petrum van Cleef, Hagae-Comitum, xvi + $28+451$ pp.

Spence Bate, C. (1888) Report on the Crustacea Macrura collected by the Challenger during the years 1873-76. Report on the Scientific Results of the Voyage of H.M.S. "Challenger" during the years 1873-76, 24, i-xc + 1-942, pls. 1-157.

Smith, S.I. (1873) Crustacea. In: Verrill, A.E., Report upon the invertebrate animals of Vineyard Sound and the adjacent waters, with an account of the physical characters of the region. Report of the Commissioner for 1871 and 1872, United States Commission of Fish and Fisheries, 1, 545-580.

Stimpson, W. (1871) Notes on North American Crustacea, in the Museum of the Smithsonian Institution. No. III. Annals of the Lyceum of Natural History in New York, 10 (6), 92-136. [title page of whole Vol. bears date 1874]

Terossi, M., De Grave, S. \& Mantelatto, F.L. (2017) Global biogeography, cryptic species and systematic issues in the shrimp genus Hippolyte Leach, 1814 (Decapoda: Caridea: Hippolytidae) by multimarker analyses. Scientific Reports, 7, e6697. https://doi.org/10.1038/s41598-017-06756-1

Udekem d'Acoz, C. d' (2007) New records of Atlantic Hippolyte, with the description of two new species, and a key to all Atlantic and Mediterranean species (Crustacea, Decapoda, Caridea). Zoosystema, 29, 183-207.

Wirtz, P. (2018) New records of marine invertebrates from São Tomé and Príncipe, eastern Atlantic Ocean. Arquipélago. Life and Marine Sciences, 35, 41-46.

Zariquey Álvarez, R. (1953) Decápodos españoles VII. Algo sobre Hippolytidae de las costas N.E. de España. Publicaciones del Instituto de Biología Alpicada, 13, 103-109. 